症例

受傷後 7 年を経て発症した外傷性横隔膜ヘルニアの 1 例

順天堂大学第 2 外科（主任：二川俊二教授)

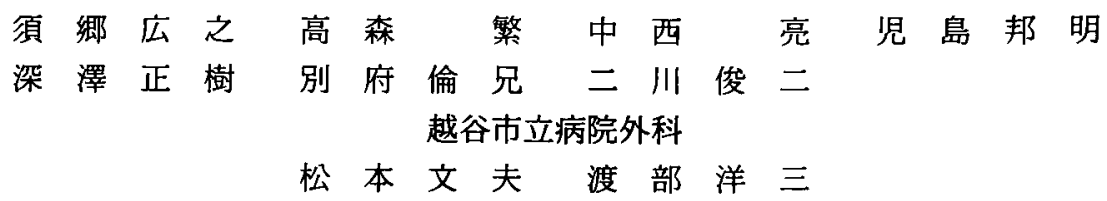

腸閉塞症状で急激に発症した外傷性横隔膜へルニアの 1 例を経験したので報告する. 症例は33歳, 男性. 突然の左側腹部痛と嘔吐を主訴に来院. 既往歷として 7 年前, 左前 胸部をナイフで自傷, 血気胸となり保存的に治療された。また発症 6 力月前, 食欲不振 で当院へ入院し単純 $\mathrm{X}$ 線検查で左下肺野に異常陰影を指摘されていた. 入院時, 単純 $\mathrm{X}$ 線検査で胸腔内の消化管ガス像と上行, 横行結腸の著明な拡張を認めたため閉塞期外傷 性横隔膜へルニアと診断, 緊急手術を施行した. 開腹時, 左横隔膜腱中心部に直径 $5 \mathrm{~cm}$ の 裂孔を認め大網と横行結腸が胸腔内人嵌入していた。本症例は 7 年前の胸部外傷に起因 した慢性期の外傷性横隔膜ヘルニアが急激に閉塞期へ移行, 発症したものと考えられた. 本疾患は閉塞期への急激な移行の可能性を常に考慮し, 適切かつ積極的な治療が必要と 考えられた。

索引用語：外傷性横隔膜ヘルニア

はじめに

外傷性横隔膜ヘルニアは交通外傷, 労働災害などに 起因することが多く, 受傷早期に発症, 診断されるこ とが多い. 今回われわれは, 受傷後 7 年を経て慢性期 から急激に閉塞期に移行, 発症したまれな外傷性横隔 膜ヘルニアの 1 例を経験したので若干の文献的考察を 加え報告する。

$$
\text { 症例 }
$$

症例：33歳, 男性.

主訴: 突然の左側腹部痛, 嘔吐.

家族歴：特記すべきことなし.

既往歴：1982年より神経症のため通院。1985年自殺 目的で左前胸部をナイフで自傷し血気胸となり他院で 保存的に治療.

現病歴：1992年 5 月，前胸部不快感，食欲不振のた め精查入院. 胸部 X 線検查にて左下肺野に異常陰影を 指摘されたが経過観察となる。1992年12月腹部膨満感 あり，外来受診しグリセリン浣腸施行された．翌日夕 食後, 突然左側腹部痛, 嘔吐出現したため当院受診し

1996年 2 月 15 日受付 1997 年 2 月10日採用
た.

入院時現症：体格は中等度で栄盖状態良好. 胸部聴 診で左下肺野の呼吸音の減弱を認めた。また左胸部第 5 助間, 鎖骨中線上に長さ約 $3 \mathrm{~cm}$ の 7 年前の自傷によ る釉痕を認めた。腹部は平坦であったが左側腹部に著 明な圧痛と聴診で腸雑音の亢進を認めた。

入院時検查所見（表 1)：WBC $19,400 / \mathrm{mm}^{3}$ の著明 な上昇と血液濃縮像を認めた。

単純 $\mathrm{X}$ 線検査：胸部では左横隔膜の挙上と縦隔の 右側偏位, また左横隔膜上に消化管がス像と思われる 鏡面像を認めた（図 1).

また腹部では上行, 横行結腸の著明な拡張と鏡面像

表 1 入院時検查所見

\begin{tabular}{lc|ll}
\hline WBC & $19,400 / \mathrm{mm}^{3}$ & Amy & $138 \mathrm{IU} / l$ \\
$\mathrm{Hgb}$ & $16.8 \mathrm{~g} / \mathrm{dl}$ & Glu & $135 \mathrm{mg} / \mathrm{dl}$ \\
$\mathrm{Ht}$ & $48.0 \%$ & $\mathrm{BUN}$ & $3.8 \mathrm{mg} / \mathrm{dl}$ \\
$\mathrm{PLT}$ & $32.5 \times 10^{4} / \mathrm{mm}^{3}$ & $\mathrm{Cr}$ & $0.8 \mathrm{mg} / \mathrm{dl}$ \\
$\mathrm{TP}$ & $7.8 \mathrm{~g} / \mathrm{dl}$ & $\mathrm{Na}$ & $139 \mathrm{mEq} / l$ \\
$\mathrm{GOT}$ & $9 \mathrm{mU} / \mathrm{ml}$ & $\mathrm{K}$ & $3.9 \mathrm{mEq} / l$ \\
$\mathrm{GPT}$ & $16 \mathrm{mU} / \mathrm{ml}$ & $\mathrm{Cl}$ & $105 \mathrm{mEq} / l$ \\
T.bil & $0.8 \mathrm{mg} / \mathrm{dl}$ & $\mathrm{CRP}$ & $2.32 \mathrm{mg} / \mathrm{dl}$ \\
\hline
\end{tabular}




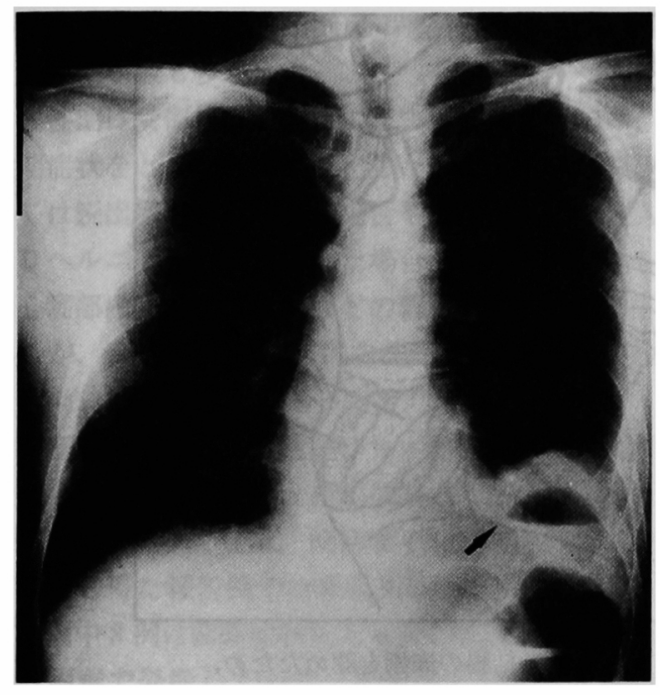

図 1 胸部単純 $\mathbf{X}$ 線検査 : 左横隔膜の挙上と縦隔の 右側偏位，また左横隔膜上に消化管ガス像（矢印） と思われる鏡面像を認めた。

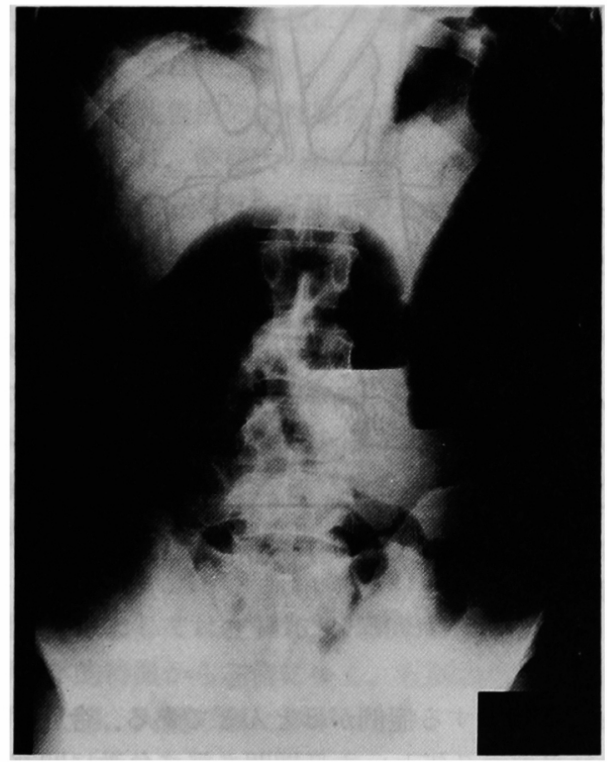

図 2 腹部単純 $\mathrm{X}$ 線検査 : 上行, 横行結腸の著明な拡 張と鏡面像および, 小腸ガス像を認めたが, 結腸脾 弯曲部より肛門側の腸管ガスは設められない。

および，小腸ガス像を認めたが，結腸脾弯曲部より肛 門側の腸管ガス像は認められない（図 2 ).

胸部単純 $\mathrm{X}$ 線検查（6力月前）：左下肺野にスリガ ラス状の異常陰影を認めた（図3).

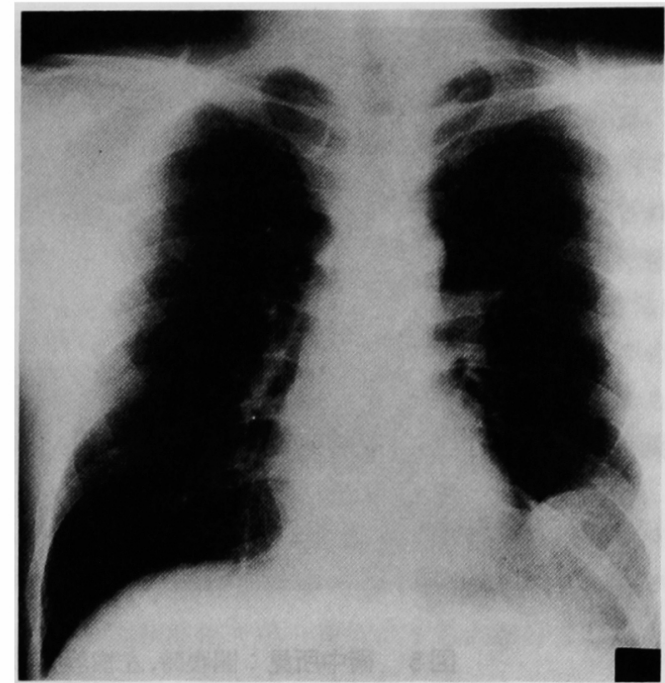

図 3 胸部単純 X 線検查 ( 6 力月前)：左下肺野にス リガラス状の異常陰影を認めるが，内部にガス像は みられない。

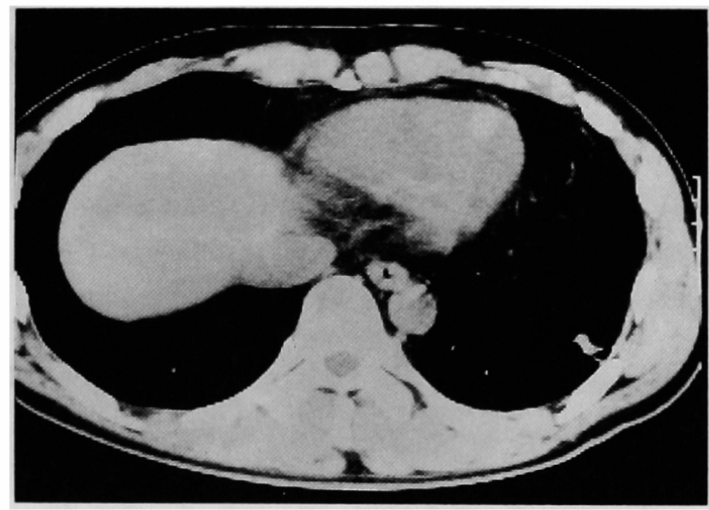

図 4 胸部 CT 検查 ( 6 力月前) : 左胸腔内に内部不均 一な Low density areaを認めた.

胸部 CT 検查 ( 6 力月前) : 左胸腔内に内部不均一な Low density area を認めるが, 消化管ガスを思わせる 鏡面像などは認められなかった（図 4 ).

以上の画像所見, 発症経過加 7 年前の外傷に起因 した横隔膜損傷部より消化管が脱出, 嵌頓した絞拒性 イレウスが疑われ緊急手術を施行した。

手術所見 : 上腹部正中切開で開腹. 左横隔膜の腱中 心部に直径 $5 \mathrm{~cm}$ 大の裂孔を認め, そこに大網と横行結 腸の一部が嵌入していた(図 5 ). 用手的に腹腔内へ還 納を試みるが裂孔部での絞扼が強いため, 裂孔に小切 開を加えて開大しこれを腹腔内へ還納した(図6)。腸 

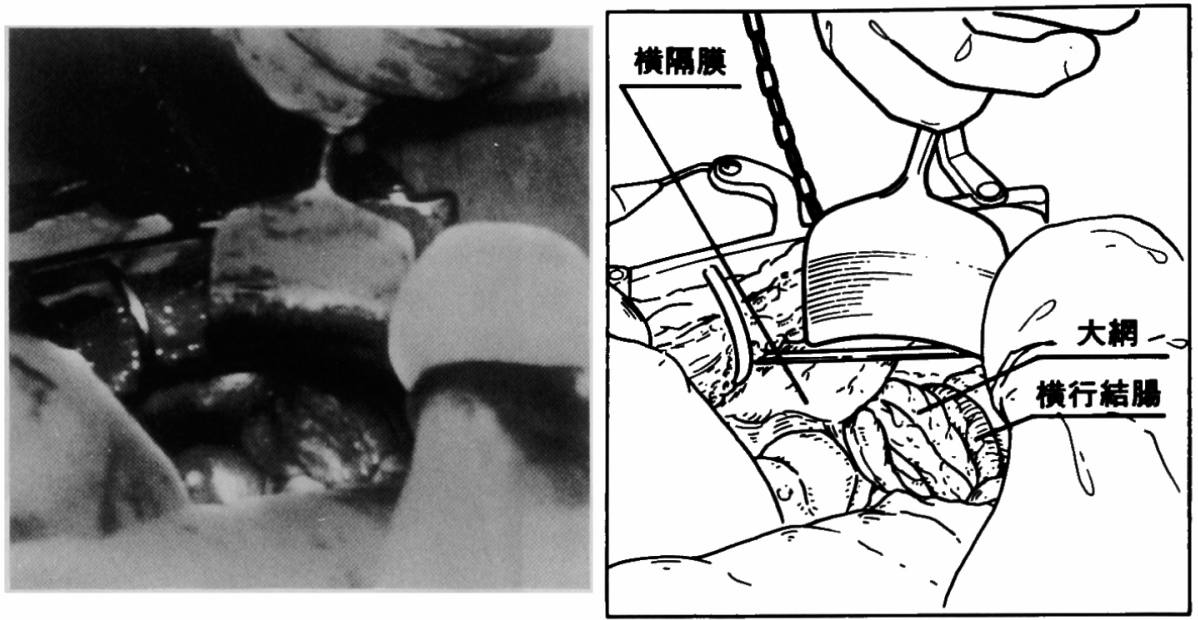

図 5 術中所見：開腹時, 左横隔膜の腱中心部に大網と横行結腸の嵌頓を認めたため, ヘルニア門に小切開を加えこれを腹腔内へ還納した。
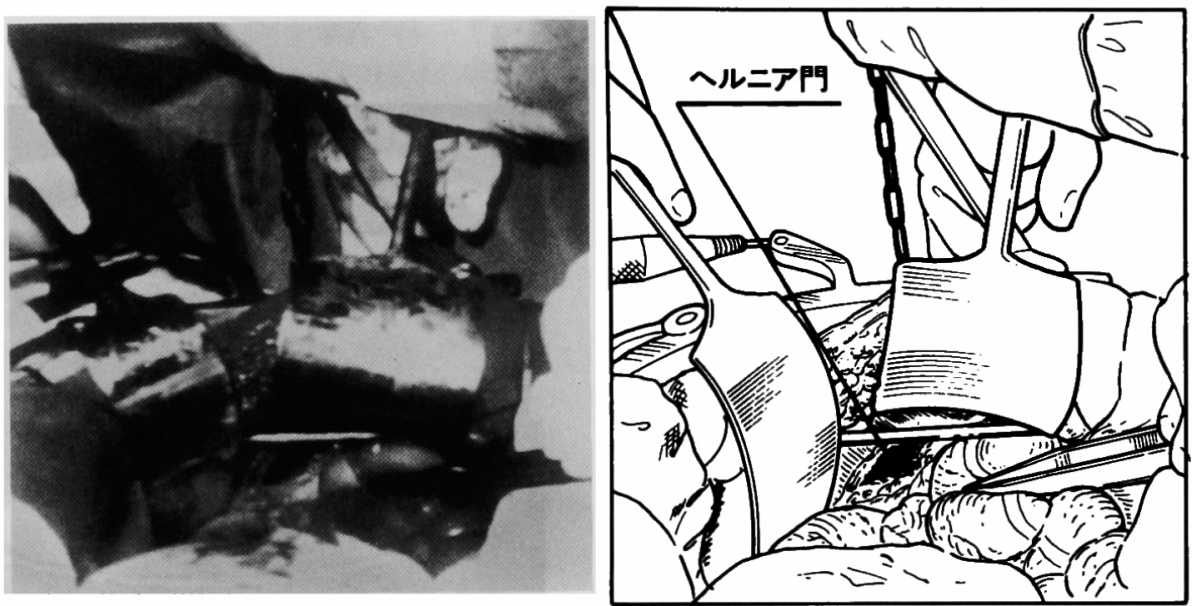

図 6 術中所見：脱出臓器と胸腔内の瘜着，血行障害は認められなかった．還納後, 直径 $5 \mathrm{~cm}$ 大のヘルニア門を確認, これを縫合閉鎖した.

管, 大網と胸腔内での癒着は認めず, 還納臓器に血行 障害はみられなかった。還納後, ヘルニア門を腹腔側 より，縫合閉鎖した，術後経過良好で術後第 16 病日に 軽快退院となった。

\section{考 察}

外傷性横隔膜ヘルニアは胸腹部外傷の $3 \sim 6 \%^{1}$ に みられる疾患であり，その多くは交通事故，労働災害 などによる多発外傷の部分症であることが多い．受傷 直後からショック, 呼吸困難, 疼痛などで発症, 診断 されることが多く, Carter ら ${ }^{2)} の$ 分類の急性期 (acute phase)に相当する症例がほとんどである. 今回，われ われは受傷後 7 年という長期間を経て急激に閉塞, 絞 扼症状で発症した閉塞期外傷性横隔膜ヘルニアのまれ な 1 例を経験したが，過去10年間（1983～95）の本邦 報告71例をあわせ, 計72例に文献的考察を加え検討し たので報告する.

外傷性横隔膜ヘルニアは発症時期から, (1)急性期 (acute phase), (2)慢性期 (interval phase), (3)閉塞絞 扼期（phase of obstruction or strangulation）の 3 期 に分類されわれわれが検索できた 72 例中, 急性期 $69 \%$ 
(50例)，慢性期18\%（13例)，閉塞絞扼期13\%（9 例） と急性期が最も多かった.

慢性期は受傷後, 無症状のまま経過したものや，急 性期症状をともなわず慢性化したもので，その原因と しては脱出臟器がわずかな場合や，大網などの嵌入に よりヘルニア門が被覆された場合が多い. 症状として は心裔部痛, 胃部不快感などの胃腸症状をみることが あるが，今回検索し得た報告例では無症候期間は 2 日”から33年4と様々であった。

閉塞絞扼期はこの慢性期から主要腹腔内臟器の脱出 をともない急激に移行, 発症することが多く，主症状 はイレウス症状である，発症までの慢性期の長さは今 回検索し得た報告例では最長30年らであり，閉塞期発 症 9 例中 8 例は前駆症状をともなわず，突然の腹痛， 呼吸困難で発症していた。自験例も発症 6 力月前の ドック入院時に胸部単純 X 線検查, $\mathrm{CT}$ 検查で左胸腔 内の異常陰影を指摘されており術中所見をあわせ考え ると， 7 年前の受傷で胸腔内人大網が嵌入しそのまま 慢性期へ移行し無症状のまま経過していたものが, 横 行結腸の嵌入, 絞扼で急激に閉塞絞扼期となり発症し たものと考えられた。

閉塞期発症報告例の慢性期から閉塞期への急激な移 行機転としては, 便秘 ${ }^{(6)}$, 運動 (ゴルフなど)" , 食事, 内視鏡検查での送気 ${ }^{8}$ など腹圧の上昇という点で共通 している。自験例も発症前日に腹部膨満感のため外来 受診し、グリセリン浣腸を施行されておりここれによ る腹圧の上昇が慢性期から閉塞期への急激な移行機転 になったものと推測された。

本症の診断で最も重要であるのは本症の特徵である 外傷の既往を確認することである。とくに慢性期や閉 塞期では受傷後長期を経て発症する場合も少なくな い.

発生部位としては左側76\%(55例)，右側 $24 \%$ (17例) と解剖学的特徵から左側に多く, 左側の場合脱出臓器 は胃，大腸，大網の順に多かった。

Carter ら 21 は左外傷性横隔膜ヘルニアの胸部単純 X 線所見として，1）左横隔膜の挙上，2）横隔膜上のガ 不像，3）縦隔の右方偏位，4）挙上横隔膜付近の無気 肺像などの特徵を強調しており，自験例においてもこ れに一致した所見がみられた。他に胃透視検查や注腸 検査で実際に胸腔内への脱出を認めれば，診断はより 確実となる。

外傷性横隔膜ヘルニアの治療は外科的手術が唯一の 治療法であり，71例全例に手術が施行されていた。手
術アプローチには開胸, 開腹, 開胸開腹の方法があり 一般的には急性期症例で胸部損傷がない場合には腹部 合併損傷の頻度が高いため開腹経路を，また経過の長 い慢性期, 閉塞絞扼期症例では脱出臟器の胸腔内での 癒着を考虑し開胸，または開胸開腹経路が推䍒されて きた ${ }^{9}$. しかし今回の自験例を含め閉塞絞扼期発症し た 9 例では開腹経路78\%( 7 例), 開胸開腹経路 $22 \%$ ( 2 例）と開腹経路が多かった。 また自験例では 7 年の経 過にもかかわらず脱出臟器と胸腔内の瘾着は認められ ず横隔膜損傷部の修復操作も腹腔内から十分可能で あった。閉塞期外傷性横隔膜ヘルニアが長期経過した 比較的高齢者に多いこと，急激で重篤な症状を呈する こと，また手術侵襲等を考虑すれば本症の手術アプ ローチは開腹経路を第一選択にするのが好ましいと考 えられた。

また自覚症状を欠く慢性期症例であっても急激な閉 塞期への移行の可能性を考え，積極的な治療が必要と 考えられた。

\section{まとめ}

受傷後 7 年を経て, 慢性期から急激に閉塞期に移行, 腸閉塞症状で発症した外傷性横隔膜へルニアのまれな 1 例を経験したので報告する。

\section{文献}

1) Orringer $M B$, Kirsh MM, Sloan $H$, et al: Congenital and traumatic diaphragmatic hernias exclusive of the hiatus. Current Problems Surgery $12: 33-64,1975$

2) Carter BN, Ginseffi J, Felson B: Traumatic diaphragmatic hernia. Am J Roentgenol Rad 65 : $56-72,1951$

3）矢野 洋, 小池 明, 小川邦泰他：鈍的胸部外傷に 奇静脈破裂と横隔膜ヘルニアを合併した 1 症例. 胸部外科 $43: 1080-1083,1990$

4）丹羽 宏, 住田紀夫, 星野輝彦他：受傷後33年経過 して発症した外傷性横隔膜へルニア. 日胸疾患会 誌 $25: 1039-1043,1987$

5）藤原敏典, 井口智浩, 藤田雄司他：受傷後 30 年を経 過して発症した閉塞期外傷性横隔膜へルニアの 1 例. 日臨外医会誌 $56: 1353-1356,1995$

6) 大橋直樹, 五嶋博道, 山碕芳生他：外傷性横隔膜人 ルニアの 2 例. 中勢病誌 $9: 29-33,1988$

7）月岡一馬, 徳原太豪, 小泉英勝他：外甥性横隔膜人 ルニア. 胸部外科 $42: 286-291,1989$

8）熊谷健二, 菊池浩太郎, 森 秀麿他：胃内空気送入 で明らかとなった外傷性横隔膜ヘルニアの 1 救命 
例. 救急医 13:1879-1881, 1989

9）森川信行, 奥田康一, 吉松泰彦他：急性期外傷性横
隔膜ヘルニアの1治験例. 日臨外医会誌 50 ： $1570-1575,1989$

\title{
A CASE OF TRAUMATIC DIAPHRAGMATIC HERNIA WHICH OCCURRED SEVEN YEARS AFTER AN ACCIDENT
}

\author{
Hiroyuki SUGO, Shigeru TAKAMORI, Ryo NAKANISHI, Kuniaki KOJIMA, \\ Masaki FUKASAWA, Tomoe BEPPU and Shunji FUTAGAWA \\ Second Department of Surgery, Juntendo University School of Medicine \\ Fumio MATSUMOTO and Yozo WATANABE \\ Department of Surgery, Koshigaya Municipal Hospital
}

We experienced a case of traumatic diaphragmatic hernia presenting with abrupt onset of ileus symptoms.

A 33-year-old man was seen at the hospital because of left hypochondriac pain with vomiting. There was a previous history of stabbing himeself in the left chest due to neurosis 7 days before. When he had a conservative treatment for hemopneumothorax. About six months before he developed these ileus symptoms, he was admitted to the hospital because of appetile loss and was pointed out having an abnormal shadow in the left lung field on simple X-ray examination. On this admission, X-ray examination showed intestinal gas in the left thoracic cavity, and extremely dilated right side of the colon. We therfore diagnosed the patient as obstructive phase of traumatic diaphragmatic hernia and performed an emergent operation. On laparotomy, a defect $5 \mathrm{~cm}$ in diameter was found at the central tendon of left diaphragm. Moreover, some part of the transverse colon and greater omentum had moved into thoracic cavity. Considering the clinical course, we regarded this case as obstructive phase of traumatic diaphragmatic hermia which had suddenly changed from chronic phase. Thus, to prevent the onset critical state, we recognise the necessity of some surgical treatment in the chronic phase considering 72 cases which have been previously reported. 